\title{
The Place of Creativity in EFL Omani Syllabus: A Content Analysis of Grade 12 Students' and Teachers' Books
}

\author{
Maryam Said Al-Jabri \\ Ministry of Education, Oman \\ https:// orcid.org/0000-0003-4553-4623
}

\author{
Fawzia Al Seyabi ${ }^{*}$, Salma Al Humaidi² and Abdulhamid Hasan $^{3}$ \\ Sultan Qaboos University \\ Al Khoudh, Muscat 123, Oman \\ ${ }^{1}$ https:// orcid.org/0000-0002-1763-3467 \\ 2https:// orcid.org/0000-0001-8579-7749 \\ ${ }^{3}$ https://orcid.org/0000-0003-4443-2342
}

\begin{abstract}
The purpose of this study was to evaluate the presence of creativity thinking skills (fluency, flexibility, originality, and elaboration) and creativity teaching strategies in post-basic English as a Foreign Language (EFL) textbooks in Oman. The content analysis method was used to analyze grade 12 EFL textbooks and Teachers' books. The researchers developed two coding books. The first coding book aimed to identify the creativity thinking skills present in the textbooks, and the other book coded the creativity teaching strategies prescribed in the Teachers' Books. The results showed that activities in post-basic EFL textbooks do not provide enough support for creativity thinking skills as only about $20 \%$ of grade 12 textbook activities included creativity thinking skills partially or fully. The findings also showed that out of the four types of creativity skills, verbal fluency was the highest. The results also indicated that the prescribed creativity teaching strategies are not very common in the EFL Teachers' Books. The study makes some recommendations for curriculum developers.
\end{abstract}

Keywords: creativity thinking skills; teaching strategies; Torrance Incubation Model; textbook analysis; Oman

\section{Introduction}

The significant role of creativity as a higher-level thinking skill in promoting the quality of education is undeniable. Previous studies have proven that studying creativity is considered a "necessity" in today's world since it is regarded as one

\footnotetext{
*Corresponding author: Fawzia Al Seyab, Email: fawzia@squ.edu.om
} 
of the factors that contribute to the progress of any civilization (Hennessey \& Amabile, 2010). Thereupon, creativity has been identified as a cornerstone in curriculum design and education development (Fatt, 2000). In particular, creative thinking activities should be present in textbooks as they play a significant role in guiding the teaching-learning processes.

Although teaching creative thinking may not seem possible to many, research in psychology has proven that creativity is a skill that can be taught (Downing, 1997; Torrance, 1963). Torrance (1963) has emphasized that schools should consider shifting their goals from teaching students how to learn into teaching them how to think (p. 4). The Torrance Incubation Model (TIM) for creative learning and teaching was developed by Paul Torrance to work as a model and guide for content design and creativity instruction (Murdock \& Keller-Mathers, 2002 b). It consists of three stages that correspond to the before, during and after stages. Murdock and Keller-Mathers (2002 b) suggested that the TIM can be used to teach creativity independently or within the specified content of any subject, including language teaching (p. 2).

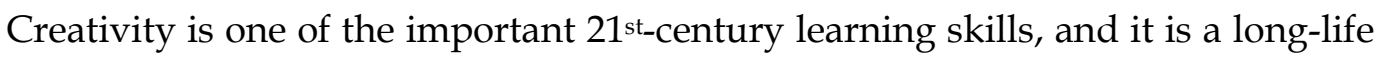
skill that contributes to improving the quality of education at different facets (Richards, 2013). These are mainly relevant to the "four Ps" that help toward shaping the creative personality: the Person, the Product, the Process, and the Place (Vogel, 2014). These four aspects of creativity are reflected in various approaches. For instance, in the humanist approach, creativity develops the personality of the students through enhancing their abilities to express themselves. For this purpose, teaching creativity requires providing safe environments in which students can explore and build up their knowledge. In so doing, the students' basic needs of security, motivation, and self-actualization in Maslow's theory of needs are fulfilled (Craft, 2001). The cognitive approach also views creativity as a combination of thinking skills that are directed to solve problems (Alhajri, 2013). This approach perceives creativity as a process that leads to the novelty of knowledge (Cropley, 1999).

This study attempts to investigate the integration of creativity thinking skills and strategies at higher school grades in Oman through a content analysis of the English as a Foreign Language (EFL) curriculum of grade 12. The study will seek to answer the following questions:

1. What type of creativity thinking skills are present in post-basic EFL textbooks?

2. What type of creativity teaching strategies are prescribed in post-basic EFL Teachers' Books?

Considering there is a gap in terms of studies that have approached creativity in the EFL context in Oman, content analysis of the EFL textbooks is considered as a starting point for future research on creativity as a $21^{\text {st-century skill. The results }}$ of the study will hopefully help to identify the weaknesses as well as the strengths of post-basic EFL textbooks in terms of integrating creativity thinking skills. Moreover, the study could provide suggestions for developing post-basic EFL textbooks in the light of the findings of the research. Identifying the present types 
of creativity thinking skills and teaching strategies could lead to more diversified inclusion of these skills and strategies in future curriculum development.

\section{Literature Review}

Treffinger, Young, Selby, and Shepardson (2002) have declared that there isn't a single definition of creativity that is approved worldwide. Therefore, describing creativity has been a hard mission for most scholars attempting to explain what creativity is and isn't (Boden, 1994), and its entire meaning is generally accepted as difficult to articulate in words. Perhaps the most favored definition of creativity is the one suggested by the National Advisory Committee on Creativity, Culture, and Education (NACCCE, 1999), which views creativity as an "imaginative activity fashioned to produce outcomes that are both original and of value." According to Shaheen (2010), this definition is applicable to the educational field in the sense that it gives room to all students to be creative.

Since the 1950s, research on creativity had thrived, starting when Guildford urged researchers to shift their attention to the skill of creativity and enrich it with more empirical studies (Craft, 2001; Jaušovec \& Jaušovec, 2011; Sternberg, 2006; ElKoumy, 2019). Guildford (1987) blamed psychologists for neglecting this field as he found very few papers that attempted to explore creativity. Consequently, a large group of scholars has endeavored to delve deeper into this field and form theories to make it more understandable, useful, and measurable. Moreover, the call for fostering creativity in education came from the world of economics after realizing the big influence of creativity in driving commerce and solving business problems (Ford \& Gioia, 2000). Also, the demand in the labor market on employees with creative visions has increased. Accordingly, embedding creativity in education has become a requirement to fulfill the job market's needs (World Bank, 2012).

\subsection{Enhancing Creativity in Education}

One common belief that surrounded the concept of creativity is that it is an inherited potential that only gifted people possess; however, this belief has started to diminish since the early twentieth century (Lin, 2011). Several studies have shed light on the effectiveness of deliberate creativity training. For example, Scott, Leritz, and Mumford's study (2004) found that creativity training has a significant positive effect on learners' creativity abilities from different age groups. Also, Fleith, Westberg, and Renzulli (2002) studied the impact of creativity training on students' divergent thinking and found positive results. Likewise, GurakOzdemir (2016) and Barker (2019) indicated that training teachers on creativity has a positive influence on enhancing their learners' creative abilities. Also, a case study conducted by Sehic (2017) concluded that students' creativity skills could be improved through language teaching and vice versa.

The communicative method is one of the educational approaches that can incorporate creativity training in foreign language teaching. The situational learning tasks used in communicative classrooms activate students' imagination and lead them eventually to think creatively (Otto, 1998; Richards, 2013). At the local level, it is clearly stated in the English Language Curriculum Framework (ELCF) (2010, p. 9) that the curriculum developers in the Oman Ministry of 
Education implemented the communicative approach in designing the textbooks. The communicative approach requires integrating different types of tasks that trigger higher-order thinking skills. According to the ELCF (2010, p. 29), the current textbooks of the post-basic stage used in Oman are rich with activities that prompt critical thinking and research skills, laying the groundwork for creative thinking to occur. However, recent studies suggest that critical thinking skills are poorly fostered in the current EFL curriculum. One recent study done by AlRajaibi (2017) concluded that there are few critical thinking skills present in the reading passages of post-basic EFL textbooks employed in Oman.

\subsection{Creative Thinking Abilities}

Studying the creative personality and the creative thinking processes have facilitated the process of understanding creativity and developed a perspective on how to enhance it in education. According to Torrance (1963), creative people are those who can sense problems in contexts, have smooth flows of ideas, and are flexible to change. They also are producers of new or unexpected answers, can see beyond the obvious, can analyze and synthesize, and do not adhere to the "right answer" or "the right way" philosophy (p. 94-97). Later, more researchers have mentioned further descriptions of creativity abilities like brainstorming and imagination (Davis, 1989).

In 1998, Torrance finalized the creativity thinking skills set in his book "Making the Creative Leap Beyond", which includes 18 skills that contribute to developing students' creative thinking abilities (Murdock \& Keller-Mathers, 2002 a). Torrance considered them as the essential skills that are developed through the Torrance Incubation Model (TIM) for creative learning and teaching (p. 9). Through utilizing these skill sets, teaching creativity becomes possible by specifying the targeted creativity thinking skills to be integrated into any type of discipline (Torrance, 1995). Among all of these skills, most studies that have attempted to measure creativity focused only on the four skills that Torrance considered in developing the Torrance Test for Creative Thinking (TTCT): fluency, flexibility, originality and elaboration (Sriwongchai, 2015; Plucker, Runco, Lim, 2006; Czarniecki, 2009; Vidal, 2005; Puryear, Kettler \& Rinn, 2017; Sarikhani, Salari \& Mansouri, 2016). These skills are tested through figural and verbal forms in the TTCT as they serve as indicators of intellectual and emotional creativity potentials (Wechsler, 2006). Therefore, this might indicate that these four skills are the most important creativity thinking skills among the ones listed in the TCSS.

\subsection{Creativity Teaching Strategies: Torrance Incubation Model for Creative Learning and Teaching}

It is difficult to imagine teaching that promotes creativity without the teaching methods themselves being creative (Sahlberg, 2009). The literature affirms that teaching creativity requires creative teaching (Sahlberg, 2009; Annarella, 1999; Richards, 2013). In other words, learners may not develop creative thinking skills if it is not encouraged by the school curriculum (Richards, 2013, p. 14). On the contrary, students may lose their interest in being creative as a result of traditional teaching strategies.

Torrance combined creativity teaching strategies in one model to guide practitioners in teaching creativity thinking skills. This model consists of three 
stages for each lesson; every stage involves some strategies that can be used in combination with other strategies or separately (Murdock \& Keller-Mathers, 2002 b). The order of these stages corresponds to the before, during and after model, but with a focus on creativity abilities (Murdock \& Keller-Mathers, 2002 b). The following figure in Torrance and Safetr's book (1990, p.8) "The Incubation Model of Teaching: Getting beyond the Aha! " illustrates the TIM strategies.

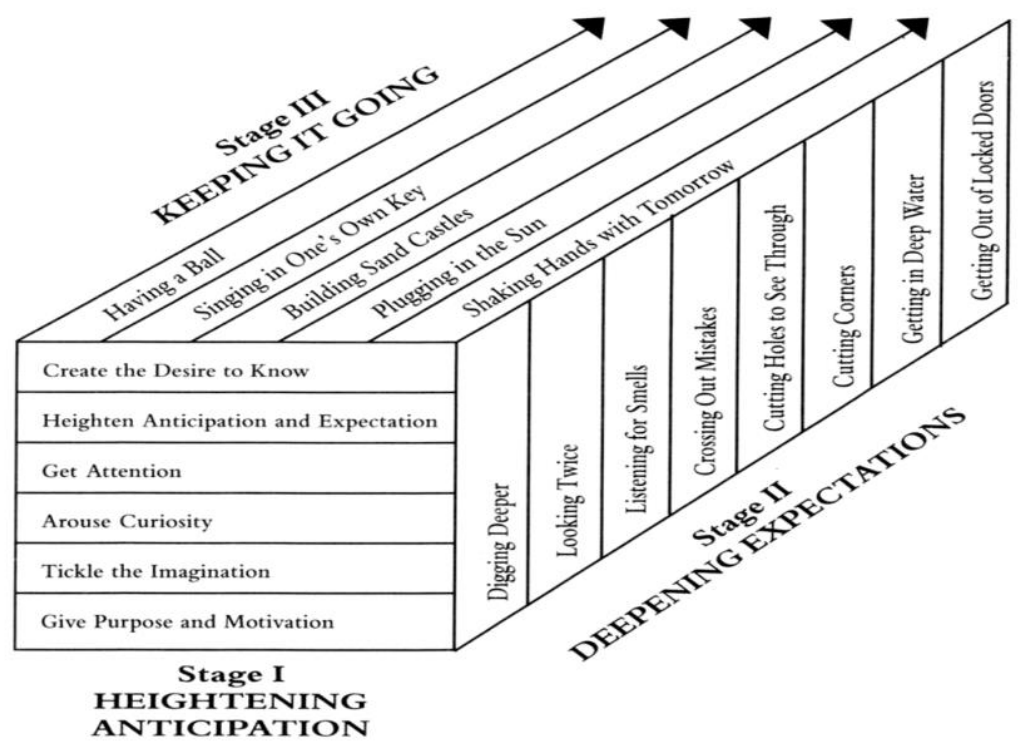

Figure 1: The Torrance Incubation Model (TIM) for Creative Learning and Teaching

According to Torrance and Safter (1990, p.12), the TIM is "a three-stage model of instruction which may be used as a guide in planning courses, planning lessons, developing instructional materials, and in making instruction more effective".

\section{Methodology}

\subsection{Research design}

To investigate the presence of creativity in education, the curriculum as a significant element of the educational environment needs to be studied to ensure that it supports creativity and creative thinking effectively. Thus, the present study used the curriculum content analysis method. The content analyzed is that of the English language textbooks and teachers' books of grade 12 in Omani public schools (of both first and second semesters). The focus of the study is directed at creativity thinking skills and creativity teaching strategies that boost creative thinking. Accordingly, students' textbooks represent the documents for the content analysis of the creativity thinking skills, and teachers' guidebooks represent the documents for the content analysis of the creativity teaching strategies.

\subsection{Sampling}

The post-basic stage of public education in Oman includes two grades, 11 and 12. As the activities and the cognitive load are cumulative throughout these two levels, grade 12 contains the highest density of activities and thinking skills. 
Moreover, it is the exit level from which students continue their education at the tertiary level or go directly into the job market. Consequently, grade $12 \mathrm{EFL}$ textbooks are the most appropriate to represent post-basic EFL textbooks of public schools. The sample includes all the activities and lessons in grade 12 students' textbooks, for both semester A and semester B. The analysis of the teaching strategies also includes all the strategies mentioned in the Teachers' books.

\subsection{Instrumentation}

Two instruments were developed by the researchers to collect data for this study. These instruments are Creativity Thinking Skills Coding Book and Creativity Teaching Strategies Coding Book. The creativity thinking skills coding book includes the primary skills listed in the Torrance Creativity Skills Set (TCSS): fluency or producing alternatives, flexibility or Look at it another way, originality and elaboration (Torrance \& Safter, 1990). These four skills are measured in figural and verbal categories according to the same classification of creativity thinking skills in the TTCT. As for the creativity teaching strategies, another coding book was developed through listing the three main stages (heightening anticipation, deepening expectation and extending the learning) of the Torrance Incubation Model for creative learning and teaching along with all the types of teaching strategies available in each stage. This coding book is used to identify the kinds of creativity strategies included in grade 12 lessons, as prescribed in the Teachers' Books of semesters A and B.

Both the validity of the instrument and reliability of analysis were established. A panel of nine instructors from Sultan Qaboos University and three Ministry of Education trainers and senior teachers validated the instruments with a few minor suggestions on the layout of the coding books. Also, inter-rater reliability and intra-rater reliability tests were developed before the actual analysis process.

\subsection{Analysis procedures}

To investigate the presence of creativity thinking skills and strategies in the content selected, the data has been analyzed based on the frequency of occurrence in each prescribed lesson in the textbooks. The frequencies are divided into three levels: commonly present, present but not common and insufficiently present. According to the scale from Man's study (2006, p. 10), the frequencies of occurrences are measured as shown in Table 1.

Table 1: Scale of Measuring Frequencies of Occurrences

\begin{tabular}{ll}
\hline Frequency level & Amount of occurrence \\
\hline Commonly present & Strategies or skills present in equal to or more than $50 \%$ of lessons. \\
$\begin{array}{l}\text { Present but not } \\
\text { common }\end{array}$ & $\begin{array}{l}\text { Strategies or skills present in equal to or more than } 33 \% \text { but less than } \\
50 \% \text { of lessons. }\end{array}$ \\
$\begin{array}{l}\text { Insufficiently } \\
\text { present }\end{array}$ & Strategies or skills present in less than $33 \%$ of lessons. \\
\hline
\end{tabular}




\section{Results}

\subsection{Types of Creativity Thinking Skills in Grade 12 EFL Textbooks}

To answer the first research question about the types of creativity thinking skills present in each lesson in grade 12 EFL textbooks, the coding of content data was performed at the unit level and the activity level.

\subsubsection{Types of Creativity Thinking Skills in the different units of grade 12 textbooks}

At the unit level, all the 20 lessons in each semester were coded, and frequencies and percentages of each creativity skill were measured, as illustrated in Table 2 . The correspondent level of presence for each type of skill is also demonstrated in the table.

Table 2: The Commonality of Presence among Types of Creativity Thinking Skills in Grade 12

\begin{tabular}{|c|c|c|c|c|c|c|c|c|c|}
\hline \multirow{2}{*}{$\begin{array}{l}\text { Creativity } \\
\text { skills }\end{array}$} & \multicolumn{2}{|c|}{ Semester A } & \multirow[t]{2}{*}{ Presence } & \multicolumn{2}{|c|}{ Semester B } & \multirow[t]{2}{*}{ Presence } & \multicolumn{2}{|c|}{ Total } & \multirow[t]{2}{*}{ Presence } \\
\hline & $F$ & $\mathrm{P}$ & & $\mathrm{F}$ & $\mathrm{P}$ & & $\mathrm{F}$ & $\mathrm{P}$ & \\
\hline \multicolumn{10}{|l|}{ Fluency } \\
\hline Figural & 0 & $0 \%$ & Not present & 0 & $0 \%$ & Not present & 0 & $0 \%$ & Not present \\
\hline Verbal & 15 & $75 \%$ & $\begin{array}{l}\text { Commonly } \\
\text { present }\end{array}$ & 17 & $85 \%$ & $\begin{array}{l}\text { Commonly } \\
\text { present }\end{array}$ & 32 & $80 \%$ & $\begin{array}{l}\text { Commonly } \\
\text { present }\end{array}$ \\
\hline \multicolumn{10}{|l|}{ Flexibility } \\
\hline Figural & 0 & $0 \%$ & Not present & 0 & $0 \%$ & Not present & 0 & $0 \%$ & Not present \\
\hline $\begin{array}{l}\text { Verbal } \\
\text { Originality }\end{array}$ & 1 & $5 \%$ & Not present & 3 & $15 \%$ & Not present & 4 & $10 \%$ & Not present \\
\hline Figural & 1 & $5 \%$ & Not present & 0 & $0 \%$ & Not present & 1 & $2.5 \%$ & Not present \\
\hline Verbal & 4 & $20 \%$ & Not present & 5 & $25 \%$ & Not present & 9 & $22.5 \%$ & Not present \\
\hline \multicolumn{10}{|l|}{ Elaboration } \\
\hline Figural & 0 & $0 \%$ & Not present & 0 & $0 \%$ & Not present & 0 & $0 \%$ & Not present \\
\hline Verbal & 2 & $10 \%$ & Not present & 8 & $40 \%$ & $\begin{array}{l}\text { present but } \\
\text { not common }\end{array}$ & 10 & $25 \%$ & Not present \\
\hline Total & 23 & $14.37 \%$ & Not present & 33 & $20.62 \%$ & Not present & 56 & $17.5 \%$ & Not present \\
\hline
\end{tabular}

Table 2 shows very little frequency of occurrences for the majority of creativity thinking skills. Figural creativity thinking skills are almost not present in both semesters. There is only one figural originality activity in workbook A (MOE, 2016c, p. 33). Among verbal creativity thinking skills, fluency has scored the most considerable frequency of occurrences in 32 lessons out of 40 in total, which indicates that verbal fluency is commonly present in the activities of grade 12 textbooks.

The occurrences of the remaining verbal creativity thinking skills range from 4 to 10 lessons out of 40 lessons in total. "Elaboration" occurred in $25 \%$ of the lessons; however, this amount shows that the skill of elaboration is not present according to the formula of analysis employed in this study. The next less frequent verbal creativity thinking skill is originality, which occurred in $22.5 \%$ of the 40 lessons, and that also indicates that this creativity skill is not present in grade 12 textbook activities. The least present verbal creativity skill is flexibility, which occurred in only four lessons in both semesters and registered a very low score of $10 \%$.

Although the percentages of most of the coded creativity thinking skills are very low, it is worthwhile to note that some lessons included more than one creativity skill, while others included only one creativity skill or none. In general, the total 
percentage of the presence of creativity thinking skills in the different units of grade 12 textbooks is $17.5 \%$. Thus, it can be concluded that students are not exposed to enough creativity thinking skills in EFL post-basic curriculum.

\subsubsection{The Level of Integration of Creativity Activities in Language Skills-Based Activities}

To gain more insights about the inclusion of creativity thinking skills in grade 12 textbooks, all language skills-based activities were coded and measured in terms of their levels of creativity thinking skills integration. These levels are (1) standalone creativity activities, (2) partial creativity activities, and (3) activities that do not include creativity thinking skills. According to the language skillsbased categorization of the units, the following table illustrates in detail the total number of textbook activities in each unit included in grade 12 textbooks for the two semesters. Total 3 in the table presents the total number of activities for each language skills-based group of units. Total 4 shows the total number of activities for each theme in every semester.

Table 3: Number of Activities in Each Unit and Theme

\begin{tabular}{|c|c|c|c|c|c|c|c|c|c|c|c|c|}
\hline \multirow{2}{*}{\multicolumn{2}{|c|}{$\begin{array}{l}\text { Units/Lessons in } \\
\text { Each Theme }\end{array}$}} & \multicolumn{10}{|c|}{ Number of textbook activities } & \multirow[b]{3}{*}{ Total 3} \\
\hline & & \multicolumn{5}{|c|}{ Semester A Themes } & \multicolumn{5}{|c|}{ Semester B Themes } & \\
\hline Unit & $\begin{array}{l}\text { Language } \\
\text { skill/area }\end{array}$ & 1 & 2 & 3 & 4 & Total 1 & 1 & 2 & 3 & 4 & Total 2 & \\
\hline 1 & Reading & 11 & 11 & 11 & 12 & 45 & 10 & 11 & 11 & 13 & 45 & 90 \\
\hline 2 & Grammar & 10 & 9 & 9 & 9 & 37 & 10 & 10 & 8 & 10 & 38 & 75 \\
\hline 3 & Vocabulary & 8 & 8 & 8 & 8 & 32 & 10 & 8 & 10 & 9 & 37 & 69 \\
\hline 4 & $\begin{array}{l}\text { Listening \& } \\
\text { speaking }\end{array}$ & 9 & 8 & 8 & 8 & 33 & 9 & 9 & 10 & 10 & 38 & 71 \\
\hline 5 & Writing & 8 & 9 & 10 & 9 & 36 & 9 & 9 & 9 & 11 & 38 & 74 \\
\hline \multicolumn{2}{|c|}{ Total 4} & 46 & 45 & 46 & 46 & 183 & 48 & 47 & 48 & 53 & 196 & 379 \\
\hline
\end{tabular}

Table 3 displays the frequencies and percentages of occurrences of creativity thinking skills in each language skills-based activity. This table highlights the level of inclusion of creativity skills in each language skill set of units in each semester separately. Moreover, Total 3 presents the total levels of creativity thinking skills inclusion in each language skill set of units in both semesters. Total 4 , on the other hand, shows the total levels of inclusion of creativity thinking skills in each semester for all language skills-based activities. 
Table 4: Level of Integration of Creativity Thinking Skills in Grade 12 A \& B Textbooks Language Skills-based Activities

\begin{tabular}{|c|c|c|c|c|c|c|c|c|c|c|c|c|c|c|c|c|c|c|c|}
\hline \multirow{4}{*}{$\dot{\overrightarrow{\vec{B}}}$} & \multirow{4}{*}{$\begin{array}{l}\text { Language } \\
\text { skills }\end{array}$} & \multicolumn{12}{|c|}{ Levels of integration } & & & & & & \\
\hline & & \multicolumn{6}{|c|}{ Semester A } & \multicolumn{6}{|c|}{ Semester B } & \multicolumn{6}{|c|}{ Total 1} \\
\hline & & \multicolumn{2}{|c|}{$\begin{array}{l}\text { No } \\
\text { Inclusion }\end{array}$} & \multicolumn{2}{|c|}{ Partial } & \multicolumn{2}{|c|}{$\begin{array}{l}\text { Stand } \\
\text { Alone }\end{array}$} & \multicolumn{2}{|c|}{\begin{tabular}{|l|} 
No \\
Inclusion
\end{tabular}} & \multicolumn{2}{|c|}{ Partial } & \multicolumn{2}{|c|}{$\begin{array}{l}\text { Stand } \\
\text { alone }\end{array}$} & \multicolumn{2}{|c|}{\begin{tabular}{|l|} 
No \\
inclusion
\end{tabular}} & \multicolumn{2}{|c|}{$\begin{array}{l}\text { Partial } \\
\text { inclusion }\end{array}$} & \multicolumn{2}{|c|}{ Stand alone } \\
\hline & & $\bar{F}$ & $\mathbf{P}$ & $\mathbf{F}$ & $\mathbf{P}$ & $\mathbf{F}$ & $\mathbf{P}$ & $\mathbf{F}$ & $\mathbf{P}$ & $\mathbf{F}$ & $\mathbf{P}$ & $\mathbf{F}$ & $\mathbf{P}$ & F & $\mathbf{P}$ & $\mathbf{F}$ & $\mathbf{P}$ & $\mathbf{F}$ & $\mathbf{P}$ \\
\hline 1 & Reading & 40 & $88.9 \%$ & 3 & $6.7 \%$ & 2 & $4.4 \%$ & 39 & $86.7 \%$ & 0 & $0 \%$ & 6 & $13.3 \%$ & 79 & $87.9 \%$ & 3 & $3.3 \%$ & 8 & $8.8 \%$ \\
\hline 2 & Grammar & 29 & $78.4 \%$ & 4 & $10.8 \%$ & 4 & $10.8 \%$ & 32 & $84.2 \%$ & 1 & $2.6 \%$ & 5 & $13.2 \%$ & 61 & $81.3 \%$ & 5 & $6.7 \%$ & 9 & $12 \%$ \\
\hline 3 & Vocabulary & 27 & $84.4 \%$ & 3 & $9.4 \%$ & 2 & $6.3 \%$ & 26 & $70.3 \%$ & 3 & $8.1 \%$ & 8 & $21.6 \%$ & 53 & $76.8 \%$ & 6 & $8.7 \%$ & 10 & $14.5 \%$ \\
\hline 4 & $\begin{array}{l}\text { Listening \& } \\
\text { Speaking }\end{array}$ & 22 & $66.7 \%$ & 3 & $9.1 \%$ & 8 & $24.2 \%$ & 29 & $76.3 \%$ & 4 & $10.5 \%$ & 5 & $13.2 \%$ & 51 & $71.8 \%$ & 7 & $9.9 \%$ & 13 & $18.3 \%$ \\
\hline \multirow[t]{2}{*}{5} & Writing & 29 & $80.6 \%$ & 3 & $8.3 \%$ & 4 & $11.1 \%$ & 30 & $78.9 \%$ & 3 & $7.9 \%$ & 5 & $13.2 \%$ & 59 & $79.7 \%$ & 6 & $8.1 \%$ & 9 & $12.2 \%$ \\
\hline & Total 2 & 147 & $80.3 \%$ & 16 & $8.7 \%$ & 20 & $11 \%$ & 156 & $79.6 \%$ & 11 & $5.6 \%$ & 29 & $14.8 \%$ & 303 & $79.9 \%$ & 27 & $7.1 \%$ & 49 & $13 \%$ \\
\hline
\end{tabular}


Table 4 above shows that listening and speaking skills received the highest inclusion of creativity thinking skills, with $9.9 \%$ of partial inclusion and $18.3 \%$ of standalone creativity activities. Vocabulary skills also included $8.7 \%$ partial integration of creativity thinking skills and $14.5 \%$ of standalone creativity activities. The next-lowest percentage is scored by writing with $8.1 \%$ of partial inclusion and $12.2 \%$ of standalone creativity activities. Grammar scored slightly lower percentages than writing, with $6.7 \%$ of partial inclusion and $12 \%$ of standalone creativity activities. Reading scored the lowest percentage of inclusion of creativity thinking skills with only $3.3 \%$ of partial inclusion and $8.8 \%$ of standalone creativity activities. Generally, in all language skills-based activities, creativity thinking skills are not included in $79.9 \%$ of these activities, which is a very high percentage compared to the percentage of the activities with full or partial inclusion of creativity thinking skills together. This means that only about $20 \%$ of textbooks activities included creativity thinking skills partially or fully. The following bar graph illustrates the level of integration of creativity skills in language skills-based activities of grade 12 textbooks.

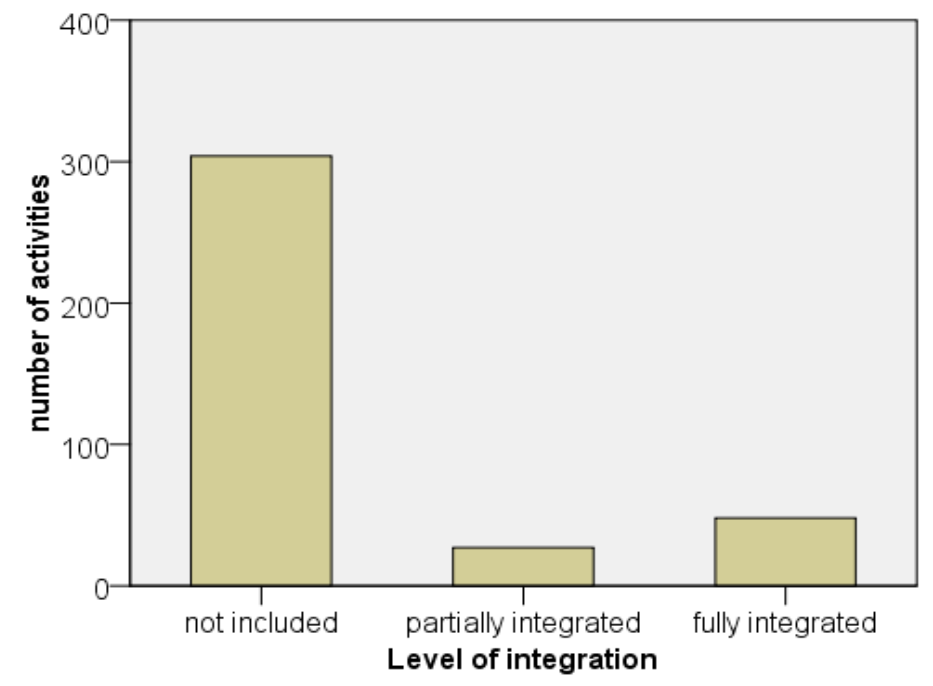

Figure 2: Levels of Integration of Creativity Thinking Skills in Grade 12 Textbook Activities

\subsection{Types of Creativity Teaching Strategies in Grade 12 EFL Teachers' Books}

To answer the second research question, the teaching strategies in the teachers' books were coded according to the guidebook designed based on the Torrance Incubation Model for creative teaching and learning. Table 5 demonstrates the frequencies and percentages of creativity teaching strategies that exist in grade 12 teachers' books along with the presence of each one of them. Totals 1 to 3 show the commonality of creativity teaching strategies for each stage in each semester while Totals 4 and 5 show the total commonality of presence in each semester and for all language skills. 
Table 5: The Commonality of Use among Types of Creativity Teaching Strategies in Grade 12 A \& B Teachers' Books.

\begin{tabular}{|c|c|c|c|c|c|c|c|c|c|}
\hline \multirow[t]{2}{*}{ TIM Strategies } & \multicolumn{2}{|c|}{ Semester A } & \multirow{2}{*}{$\begin{array}{c}\text { Commonality of } \\
\text { Presence }\end{array}$} & \multicolumn{2}{|c|}{ Semester B } & \multirow{2}{*}{$\begin{array}{c}\text { Commonality of } \\
\text { presence }\end{array}$} & \multicolumn{2}{|c|}{ Total 5} & \multirow{2}{*}{$\begin{array}{c}\text { Commonality of } \\
\text { Presence }\end{array}$} \\
\hline & $\mathbf{F}$ & $\mathbf{P}$ & & $\mathbf{F}$ & $\mathbf{P}$ & & $\mathbf{F}$ & $\mathbf{P}$ & \\
\hline \multicolumn{10}{|l|}{ Stage 1: } \\
\hline \multicolumn{10}{|l|}{ Heightening Anticipation } \\
\hline Create desire to know & 12 & $60 \%$ & Commonly present & 15 & $75 \%$ & Commonly present & 27 & $67.5 \%$ & Commonly present \\
\hline Heightening anticipation & 10 & $50 \%$ & Commonly present & 2 & $10 \%$ & Not present & 12 & $30 \%$ & Not present \\
\hline Get attention & 12 & $60 \%$ & Commonly present & 9 & $45 \%$ & Uncommonly present & 21 & $52 \%$ & Commonly present \\
\hline Arouse curiosity & 12 & $60 \%$ & Commonly present & 15 & $75 \%$ & Commonly present & 27 & $67.5 \%$ & Commonly present \\
\hline Tickle the imagination & 5 & $25 \%$ & Not present & 0 & $0 \%$ & Not present & 5 & $12.5 \%$ & Not present \\
\hline Give purpose and motive. & 11 & $55 \%$ & Commonly present & 17 & $85 \%$ & Commonly present & 28 & $70 \%$ & Commonly present \\
\hline Total 1 & 62 & $52 \%$ & Commonly present & 58 & $48 \%$ & Uncommonly present & 120 & $50 \%$ & Commonly present \\
\hline \multicolumn{10}{|l|}{ Stage 2: } \\
\hline \multicolumn{10}{|l|}{ Deepening Expectations } \\
\hline Digging deeper & 17 & $85 \%$ & Commonly present & 18 & $90 \%$ & Commonly present & 35 & $62.5 \%$ & Commonly present \\
\hline Looking twice & 10 & $50 \%$ & Commonly present & 9 & $45 \%$ & Uncommonly present & 19 & $47.5 \%$ & Uncommonly present \\
\hline Listening for smells & 8 & $40 \%$ & Uncommonly present & 5 & $25 \%$ & Not present & 13 & $32.5 \%$ & Not present \\
\hline Crossing out mistakes & 11 & $55 \%$ & Commonly present & 9 & $45 \%$ & Uncommonly present & 20 & $50 \%$ & Commonly present \\
\hline Cutting holes & 7 & $35 \%$ & Uncommonly present & 13 & $65 \%$ & Commonly present & 20 & $50 \%$ & Commonly present \\
\hline Cutting corners & 6 & $30 \%$ & Not present & 8 & $40 \%$ & Uncommonly present & 14 & $35 \%$ & Uncommonly present \\
\hline Getting in deep water & 10 & $50 \%$ & Commonly present & 10 & $50 \%$ & Commonly present & 20 & $50 \%$ & Commonly present \\
\hline Getting out of locked drs. & 4 & $20 \%$ & Not present & 7 & $35 \%$ & Uncommonly present & 11 & $27.5 \%$ & Not present \\
\hline Total 2 & 73 & $46 \%$ & Uncommonly present & 79 & $49 \%$ & Uncommonly present & 152 & $48 \%$ & Uncommonly present \\
\hline \multicolumn{10}{|l|}{ Stage 3: Keep it Going } \\
\hline Having a ball & 4 & $20 \%$ & Not present & 4 & $20 \%$ & Not present & 8 & $20 \%$ & Not present \\
\hline Singing in one's own key & 6 & $30 \%$ & Not present & 3 & $15 \%$ & Not present & 9 & $22.5 \%$ & Not present \\
\hline Building sandcastles & 12 & $60 \%$ & Commonly present & 15 & $75 \%$ & Commonly present & 27 & $67.5 \%$ & Commonly present \\
\hline Plugging in the sun & 3 & $15 \%$ & Not present & 7 & $35 \%$ & Uncommonly present & 10 & $25 \%$ & Not present \\
\hline Shaking hands & 2 & $10 \%$ & Not present & 2 & $10 \%$ & Not present & 4 & $10 \%$ & Not present \\
\hline Total 3 & 27 & $27 \%$ & Not present & 31 & $31 \%$ & Not present & 58 & $29 \%$ & Not present \\
\hline Total 4 & 162 & $42 \%$ & Uncommonly present & 168 & $44 \%$ & Uncommonly present & 330 & $43 \%$ & Uncommonly present \\
\hline
\end{tabular}


Table 5 indicates that the frequency of occurrences of creativity teaching strategies varies in different stages. The total percentages of stage 1 show that it includes four commonly present creativity teaching strategies which are: Create the desire to know, Get attention, Arouse curiosity, and Give purpose and motivation. There are two other "not present" creativity teaching strategies in stage 1, which are: Heightening anticipation and Tickle the imagination. The total percentage indicates that creativity teaching strategies for stage 1 of the Torrance Incubation Model are commonly present in grade 12 prescribed lesson plans.

The variation is wider concerning the creativity teaching strategies in stage 2 with four commonly present strategies: Digging deeper, Crossing out mistakes, Cutting holes to see through, and Getting in deep water. There are a few uncommonly present creativity teaching strategies, which are: Looking twice and Cutting corners. Besides, two more strategies are not present: Listening for smells and Getting out of locked doors. The overall percentage of the second stage shows that creativity teaching strategies for this stage are uncommonly present in grade 12 prescribed lesson plans.

As for the creativity teaching strategies in stage 3, the table shows a very low frequency of occurrences for most of them except for one strategy, which is Building sandcastles. The rest of the strategies scored lower percentages than 33\%, which means that they are not present in the prescribed lesson plans. In total, creativity teaching strategies in stage 3 are not present based on the previously mentioned scale. Generally, creativity teaching strategies scored $43 \%$ for both semesters in total, which confirms that these strategies are present in grade 12 teachers' books, but they are not common.

Appendix A presents examples of some creativity teaching strategies from grade 12 teachers' books A and B.

\section{Discussion}

\subsection{Creativity thinking skills in students' textbooks}

According to the results of this study, the presence of creativity thinking skills in postbasic EFL textbooks activities is minimal. Fewer than $20 \%$ of the prescribed lessons included creativity skills, and almost $20 \%$ of language skills-based activities included creativity skills. This finding is expected since it aligns with the results of previous studies that also sought to evaluate the presence of creativity thinking skills in textbooks activities. Baleghizadeh and Dargahi (2016), for instance, have analyzed six international ESL textbooks and found that only two of these textbooks included more than $50 \%$ of creative activities while the rest have scored very low percentages of creativity skills inclusion.

Figural creativity thinking skills are not present in post-basic EFL textbooks.

Among all the 379 activities in the EFL textbooks of grade 12 for both semesters, only one activity included figural creativity thinking skills. This result indicates that figural creativity thinking skills are ignored at the post-basic level. This omission can be justified since the focus of language teaching is usually directed at verbal efficiency. Dău-Gaşpar (2013) has put this assumption under examination and concluded that high school students function better at figural tasks than verbal ones. This result emphasizes the importance of including figural creativity activities in EFL textbooks at this stage. Moreover, a study by Chan and Chan (2007) in Hong Kong to explore the relationship 
between Chinese high school students' drawing abilities and their creativity abilities found that these two variables are positively correlated. Also, according to Hummel (1988), one of the significant characteristics of textbooks that encourage self-directed learning is to stimulate creativity through drawing and crafting tasks. Moreover, figural creativity has a positive influence on learners' reading comprehension and recall abilities. An experimental study conducted by Ghazanfari (2011) confirmed that students who practice mental visualization of the texts before, during and after reading tasks perform better than learners who are not exposed to this strategy.

Verbal fluency is commonly present in post-basic EFL textbooks.

Verbal fluency is the only commonly present creativity skill in the textbooks analyzed, which is not surprising since these textbooks are designed based on the communicative approach, as mentioned earlier. One of the primary purposes of communicative language teaching or CLT is to provide learners with as many opportunities to develop verbal fluency (Gatbonton \& Segalowitz, 1988; Renukadevi, 2016). CLT is one of the most effective approaches that can enhance learners' verbal fluency because of the communicative teaching techniques, such as games and roleplays that are practiced in communicative classrooms. Oral fluency is also mentioned as an independent objective in the framework of the English language curriculum at the post-basic level (ELCS, 2010, p. 25).

This finding aligns with other studies that have attempted to analyze language textbooks for creativity skills. Alhawamda and Bani-Issa (2013), for example, analyzed Arabic language textbooks for grade six and found that verbal fluency is the most common among the other four creativity skills. Also, Alfara (2010) analyzed activities in Arabic textbooks of grade four and reached a similar result. However, the ideas or solutions required by the verbal fluency activities in grade $12 \mathrm{EFL}$ textbooks are limited to a certain number in many cases, which is at odds with the essential meaning of fluency: to unleash ideas and let them flow freely. Moreover, most of these activities are explained in detail with numerous examples; consequently, this can also lead to putting students' ideas in a specific, narrow framework and limiting their range of thought. A similar result was also found by Halaq (2017) when analyzing Arabic textbooks at the primary stage of basic education.

Verbal flexibility, verbal originality, and verbal elaboration are not present in post-basic EFL textbooks.

The results of the study show few frequencies for these three skills, verbal flexibility, verbal originality, and verbal elaboration in grade 12 EFL textbooks in both semesters. It can be assumed that the inclusion of this amount of creativity activities is spontaneous as part of the activities that are designed to encourage higher-order thinking and research skills that are listed among the objectives of post-basic grades in the ELCF (ELCS, 2010, p. 25). Similar studies have also found that the presence of these skills is weak in language teaching textbooks (Alhawamda \& Bani-Issa, 2013; Alfara, 2010).

Language skills-based activities in the post-basic EFL textbooks do not offer enough support for improving creativity skills.

As shown in Table 5, all the language skills-based activities included small percentages of creativity skills in partial or full integration. Although the highest percentage was scored by listening and speaking skills-based activities, which comprised $28.2 \%$ of creativity 
skills in total, this percentage fell under the "not commonly present level." Besides, this percentage represents the inclusion of creativity skills for activities of two language skills, unlike the other percentages of the other language skills-based activities. Another reason for that could be the emphasis on developing oral fluency in the curriculum objectives (ELCS, 2010, p. 25).

Vocabulary activities fell into the second-highest percentage level, with $23.2 \%$ of creativity skills. These activities generally included tasks like listing relevant words, guessing meaning from context, or making sentences or short stories from given words. The objectives related to improving learners' vocabulary put stress on the importance of exposing them to a wide range of texts and high-frequency words through recycling familiar words and constructing sentences based on them (ELCS, 2010). Some researchers like Seddigh and Shokrpour (2013) and Nosratinia and Zaker (2015) have attempted to identify the relationship between creativity and vocabulary learning strategies and found that these two variables are significantly and positively correlated. Besides, Hajilou, Yazdani, and Shokrpour (2012) have concluded that creativity is not only correlated positively with productive vocabulary knowledge, but there is also a positive correlation between creativity and receptive knowledge of vocabulary. However, the finding of the current study indicates that creativity skills are ignored in planning for vocabulary activities in post-basic EFL textbooks.

Writing activities also scored a low percentage of creativity thinking skills inclusion, although this language skill is generally linked to creativity in what is called "creative writing." This assumption is prevalent because of the productive nature of writing and its direct relationship with imagination and mental visualization (Sharples, 2002, p. 8). This relationship is clarified by Lambirth, Grainger, and Goouch (2005) when they stated that "a creative activity is goal-oriented and the creative act of writing self-evidently involves making; making connections, making meaning, composing and communicating" (p.13).

Nevertheless, the objective related to writing skills in the ELCF highlights the importance of the process of "writing with a balance between fluency-based and accuracy-based tasks." The ELCF also mentions other specific objectives which focus on types of texts that students can produce using higher-order thinking skills (ELCS, 2010). Therefore, it can be concluded that these few writing activities are designed as part of the general orientation of the communicative approach but not for enhancing creativity thinking skills.

It is no surprise that grammar and reading activities score lowest in terms of creativity skills, with less than $20 \%$ of inclusion. Grammar as a language skill is generally considered by many teachers and students to be rigid (Nagaratnam \& Al-Mekhlafi, 2012), which contradicts with the free and flexible nature of creativity. The ELCF mentions briefly that grammar should be taught inductively and deductively in a balanced manner (p. 25); however, there isn't much explanation or detail about how grammar is expected to be taught at this stage. As for reading, the ELCF includes some details about the types of genres of the texts and the kinds of reading strategies that students should practice.

This also indicates that the slight inclusion of creativity thinking skills in language skillsbased activities is unstructured. Alkiyumi (2010) has also noted that grade 10 curricula, which is immediately preceding the post-basic stage, do not include tasks or strategies that activate creative thinking. 


\subsection{Creativity teaching strategies in post-basic EFL Teachers' Books}

Stage 1: Creativity teaching strategies are commonly present in post-basic EFL Teachers' Books. The results of the current study reveal a common presence of creativity teaching strategies of the first stage of the TIM in post-basic EFL Teachers' Books. This can be attributed to the sequence and structure of activities, which include lead-in elements that help learners to be motivated and engaged in the content of the lessons. As noticed by the researchers, the lead-in elements exist as independent introductory activities and within the beginnings of some activities as well, which correspond to the warm-up stage of Torrance's model: Heightening Anticipation (Torrance \& Safter, 1990). Warm-up activities, according to Torrance, are those that help learners link the new content to something meaningful to them and increase their interests to know more about the topic. Similarly, the ELCF mentions that the "affective factor" is taken into consideration with motivating activities that draw learners' personal experiences into the learning processes (p. 11). Therefore, this mutual perspective explains why strategies in the first stage of TIM are commonly present in the analyzed EFL textbooks.

Stage 2: Creativity teaching strategies are present but not common in post-basic EFL Teachers' Books.

The strategies prescribed in the second stage are present, but they are not common in grade 12 prescribed lesson plans as the results suggest. The most commonly present strategy in this stage is digging deeper, which aligns with Man's study (2006), who also found it as a widely used strategy by teachers who used TIM spontaneously in their lesson plans. This strategy includes searching for more in-depth information, synthesizing, diverging, and evaluating skills (Torrance \& Safter, 1990), which are types of critical thinking skills (Snyder \& Snyder, 2008). Hence, the communicative skills-based activities of the post-basic EFL curriculum are designed to foster critical thinking skills and searching skills (ELCS, 2010).

Stage 3: Creativity teaching strategies are not present in post-basic EFL Teachers' Books.

According to Table 5 in the results section, strategies of the third stage in the TIM are not present in the analyzed textbooks. Building sandcastles is the only commonly present strategy among the five strategies, which also aligns with Man's study (2006), who found it as the only commonly used strategy in the participants' lesson plans. This strategy includes using the content as a basis for searching for ideal solutions, which also, according to Snyder and Snyder (2008), is related to critical thinking skills. One of the strategies of the third stage is shaking hands with tomorrow, which is mainly related to linking the content of the subject to the learners' vocational or educational future (Torrance \& Safter, 1990). Surprisingly, this strategy scored the lowest percentage of presence despite the claim that the activities of the EFL textbooks of grade 12 are designed to prepare students for their future careers (Ministry of Education, 2016a, p. xii).

\section{Conclusion}

The study aimed to explore the present situation of creativity in Omani post-basic EFL textbooks by investigating the presence of four primary creativity thinking skills: fluency, flexibility, originality, and elaboration at figural and verbal categories. Besides, the study investigated the presence of a set of creativity teaching strategies from the TIM by analyzing the prescribed teaching strategies. 
The method used in collecting data was content analysis design, which was carried out through reviewing the recently edited versions of students' textbooks and Teachers' Books produced by the MOE. Two coding books were developed and used by the researchers to collect data from the mentioned documents, and reliability of analysis and validity of instruments were ensured.

The results of the study showed a fragile presence of creativity thinking skills in the analyzed language skills-based activities. However, the analysis revealed that creativity teaching strategies are present in the prescribed teaching strategies for post-basic EFL activities, but they are not common.

\section{Recommendations}

Some useful recommendations can be considered for future reform to consolidate creativity in EFL teaching in the post-basic stage. The Oman Ministry of Education can refer to the results of the recent studies which have focused on the presence of critical thinking skills and creativity thinking skills in the current EFL curriculum and consider them in its future reform of textbooks. There also seems to be a need to initiate more workshops for teachers on creativity thinking skills and teaching strategies. As for curriculum developers, they can include creativity skills in the EFL textbook activities following a well-planned vision for fostering creative thinking in the post-basic stage. It is also highly recommended to diversify the creativity skills in each lesson across the curriculum with a variety of creativity teaching strategies. This seems to be necessary if there is a sincere attempt to promote creativity as a long-life skill that contributes to improving not only the quality of education but also the quality of life that awaits our future generations.

\section{References}

Ada, A. F. (1988). Creative reading: A relevant methodology for language minority children. In Malave, L. M. (Ed.) NABE '87. Theory, research, and application: Selected Papers.

Buffalo: State University of New York. Retrieved from https://files.eric.ed.gov/fulltext/ED336956.pdf

Alfara, M. (2010). Analysing the textbook Lugatana Al Jamila (Our Beautiful Language) of grade four in light of creative thinking and students' acquisition of it (in Arabic) (MA dissertation, Islamic University, Ghazza, Palestine). Retrieved from https://iugspace.iugaza.edu.ps/bitstream/handle/20.500.12358/18664/file_1.pdf?seque nce $=1$ \&isAllowed $=\mathrm{y}$

Alfares, N. (2014). Using the textbook to promote thinking skills in intermediate school EFL classrooms in Saudi Arabia: An analysis of the tasks and an exploration of teachers' behaviours and perceptions (Doctoral dissertation, University of Glasgow, Scotland, UK). Retrieved from http://theses.gla.ac.uk/id/eprint/5566

Alhajri, S. (2013). Developing a pedagogical model to enhance and assess creativity in Omani graphic design education (Doctoral dissertation, Loughborough University, London, UK). Retrieved from https://dspace.lboro.ac.uk/2134/12357

Alhawamda, M., \& Bani- Issa, M. (2013). Creative Reading Skills in Grade Six Arabic Textbooks (in Arabic). Journal of Islamic University of Educational and Psychological Studies, 3(21), 377401. 
Alkiyumi, M. (2010). Creative thinking and problem-solving abilities: Their relationship with psychological traits among 10th-grade students in Oman. (Doctoral dissertation, University Sains Malaysia, Penang, Malaysia). Retrieved from http://eprints.usm.my/id/eprint/28865

Al-Rajaibi, M. A. (2017). Analysis of the reading comprehension passages and questions in grades 11 and 12 Omani EFL textbooks with regard to critical thinking skills. (Master's thesis, Sultan Qaboos University, Muscat, Sultanate of Oman).

Annarella, L. A. (1999). Encouraging creativity and imagination in the classroom. Opinion papers. Retrieved from https:/ / files.eric.ed.gov/fulltext /ED434380.pdf

Barker, I. (2019). Creativity and high potential gifted education discussion paper author draft. State of New South Wales, Australia: NSW Department of Education. https://doi.org/10.13140/RG.2.2.20818.71360

Baleghizadeh, S., \& Dargahi, Z. (2016). What aspects of creativity enhancement do ELT textbooks take into account? In B. Tomlinson (ed.), SLA research and materials development for language learning, (pp. 185 - 197). London, England: Routledge.

Boden, M. A. (1994). Dimensions of creativity. Cambridge, MA: MIT Press. https://doi.org/10.7551/mitpress/2437.001.0001

Bouzid, H. A. (2016). Boosting 21 st century skills through Moroccan ELT textbooks. Journal of English Language Teaching and Linguistics, 1(2), 97-108. https://doi.org/10.21462/jeltl.v1i2.24

Chan, D. W., \& Chan, L. K. (2007). Creativity and drawing abilities of Chinese students in Hong Kong: is there a connection. New Horizons in Education, 55(3), 77-94. Retrieved from https:/ / files.eric.ed.gov/fulltext/EJ832894.pdf

Craft, A. (2001). An analysis of research and literature on creativity in education. Qualifications and Curriculum Authority, 51(2), 1-37. Retrieved from https://pdfs.semanticscholar.org/b26f/f91d08b36522a301e23c84130e8922284e26.pdf

Cropley, A. J. (1999). Creativity and cognition: Producing effective novelty. Roeper Review, 21(4), 253-260. https://doi.org/10.1080/02783199909553972

Czarniecki, L. (2009). Teacher impact on student creativity (Master's thesis, The Evergreen State College, WA, USA). Retrieved from https:/ / bit.ly/2Dgklh7

Dău-Gaşpar, O. (2013). Verbal and figural creativity in contemporary high-school students. Procedia-Social and Behavioral Sciences, 78, 662-666. https://doi.org/10.1016/j.sbspro.2013.04.371

Davis, G. A. (1989). Testing for creative potential. Contemporary Educational Psychology, 14(3), 257274. https:// doi.org/10.1016/0361-476X(89)90014-3

Downing, J. P. (1997). Creative teaching: Ideas to boost student interest. Englewood, CO: Teacher Ideas Press.

El-Koumy, A. S. (2019). A multifaceted framework for EFL curriculum development to prepare students for building a 21st century Egypt. Giza, Egypt: Modern Academy for University Books. Retrieved from https:/ /files.eric.ed.gov/fulltext/ED602290.pdf

Fatt, J. P. T. (2000). Fostering creativity in education. Education, 120(4), 744-757.

Ford, C. M., \& Gioia, D. A. (2000). Factors influencing creativity in the domain of managerial decision making. Journal of Management, 26(4), 705-732. https:// doi.org/10.1177/014920630002600406

Fleith, D. D. S., Renzulli, J. S., \& Westberg, K. L. (2002). Effects of a creativity training program on divergent thinking abilities and self-concept in monolingual and bilingual classrooms. Creativity Research Journal, 14(3-4), 373-386. https://doi.org/10.1207/S15326934CRJ1434_8 
Gatbonton, E., \& Segalowitz, N. (1988). Creative automatization: Principles for promoting fluency within a communicative framework. TESOL Quarterly, 22(3), 473-492. https://doi.org/10.2307/3587290

Ghazanfari, M. (2011). The role of visualization in EFL learners' reading comprehension and recall of short stories. Iranian Journal of Applied Language Studies, 1(1), 1-23. Retrieved from http://ijals.usb.ac.ir/article_43_a86d7ed4ea03beaefeaa3474eded2f77.pdf

Guildford, J. (1987). Creativity research: Past, present and future. Frontiers of Creativity Research: Beyond the Basic. Buffalo, NY: Bearly.

Gurak-Ozdemir, S. (2016). Teachers' perceptions of students' creativity characteristics. (Master's Theses, The State University of New York, Buffalo State, USA). Retrieved from https://digitalcommons.buffalostate.edu/creativetheses/28

Hajilou, Y., Yazdani, H., \& Shokrpour, N. (2012). The relationship between Iranian EFL learners' creativity and their lexical reception and production knowledge. English Language Teaching, 5(3), 131. https://doi.org/10.5539/elt.v5n3p131

Hennessey, B. A., \& Amabile, T. M. (2010). Creativity. Annual Review of Psychology, 61, 569-598. https://doi.org/10.1146/annurev.psych.093008.100416

Hummel, C. (1988). School textbooks and lifelong education: An analysis of school books from three countries. Hamburg, Germany: UNESCO Institute for Education.

Jausovec, N., \& Jausovec, K. (2011). Brain, creativity and education. The Open Education Journal, 4(1). https://doi.org/10.2174/1874920801104010050

Lambirth, A., Grainger, T., \& Goouch, K. (2005). Creativity and writing: Developing voice and verve in the classroom (1 ${ }^{\text {st }} \mathrm{ed}$.). London, England: Routledge. https://doi.org/10.4324/9780203391075

Lin, Y. S. (2011). Fostering creativity through education-a conceptual framework of creative pedagogy. Creative Education, 2(3), 149. https://doi.org/10.4236/ce.2011.23021

Man, K. (2006). Exploring the use of the Torrance Incubation Model in the design of lessons in Art Explore (Unpublished paper). Buffalo State College, Buffalo State, USA.

Murdock, M. C., \& Keller-Mathers, S. (2002a). The foundations of the Torrance Incubation Model: Identifying and using a creativity skill set. National Association of Gifted Children's Celebrate Creativity Newsletter, 12(2), 5-6. Retrieved from https://www.scribd.com/document/324342587/Three-Articles-an-Overview-of-TIM

Murdock, M., \& Keller-Mathers, S. (2002 b). Teaching for creativity: Where there's a will, there's a way. National Association of Gifted Children Celebrate Creativity Newsletter, 13(2), 3.

Retrieved from https://www.scribd.com/document/324342587/Three-Articles-anOverview-of-TIM

National Advisory Committee on Creative and Cultural Education (NACCCE). (1999). All our futures: Creativity, culture and education. London, England: Department for Education and Employment. Retrieved from http://www.readyunlimited.com/wpcontent/uploads/2013/02/all-our-futures1.pdf

Nagaratnam, R. P., \& Al-Mekhlafi, A. (2012). Attitudes towards EFL grammar instruction: Inductive or deductive. FLLT Journal, 1(2), 78-105.

Nosratinia, M., \& Zaker, A. (2015). Boosting autonomous foreign language learning: Scrutinizing the role of creativity, critical thinking, and vocabulary learning strategies. International Journal of Applied Linguistics and English Literature, 4(4), 86-97. https:// doi.org/10.7575/aiac.ijalel.v.4n.4p.86

Ottó, I. (1998). The relationship between individual differences in learner creativity and language learning success. TESOL Quarterly, 32(4), 763-773. https://doi.org/10.2307/3588011 
Plucker, J. A., Runco, M. A., \& Lim, W. (2006). Predicting ideational behaviour from divergent thinking and discretionary time on task. Creativity Research Journal, 18(1), 55-63. https://doi.org/10.1207/s15326934crj1801_7

Puryear, J. S., Kettler, T., \& Rinn, A. N. (2017). Relationships of personality to differential conceptions of creativity: A systematic review. Psychology of Aesthetics, Creativity, and the Arts, 11(1), 59. https://doi.org/10.1037/aca0000079

Renukadevi, D. (2016). Communicative approach in teaching English as L2: An overview. Language in India, 16(4).

Richards, J. C. (2013). Creativity in language teaching. Iranian Journal of Language Teaching Research, 1(3), 19-43. Retrieved from https:/ / files.eric.ed.gov/fulltext/EJ1127396.pdf

Sahlberg, P. (2009). The role of education in promoting creativity: potential barriers and enabling factors. In E. Villalba (ed.), Measuring Creativity: Proceedings for the Conference, "Can Creativity Be Measured?" (pp. 337-344). Brussels, Luxemburg: Publications Office of the European Union. Saito, E., \& Atencio. Retrieved from https://www.greenschool.org/wp-content/uploads/2012/03/Pasi-Sahlberg.pdf

Sarikhani, R., Salari, M., \& Mansouri, V. (2016). The impact of e-learning on university students' academic achievement and creativity. Journal of Technical Education and Training, 8(1). Retrieved from http:// penerbit.uthm.edu.my/ojs/index.php/JTET/article/view/1152

Scott, G., Leritz, L. E., \& Mumford, M. D. (2004). The effectiveness of creativity training: A quantitative review. Creativity Research Journal, 16(4), 361-388. https://doi.org/10.1207/s15326934crj1604_1

Sehic, S. (2017). The effect of English language learning on creative thinking skills: A mixed methods case study. English Language Teaching, 10(3), 82-94. https://doi.org/10.5539/elt.v10n3p82

Seddigh, F., \& Shokrpour, N. (2013). Creativity and its relationship with vocabulary learning strategy use of EFL students. Journal of Studies in Education, 3(2), 139-151. https://doi.org/10.5296/jse.v3i2.3199

Shaheen, R. (2010). The place of creativity in Pakistani Primary Education System: An investigation into the factors enhancing and inhibiting primary school children's creativity (Doctoral dissertation, University of Birmingham, Birmingham, UK).

Sharples, M. (1999). How we write: Writing as creative design. London, England: Routledge. https://doi.org/10.4324/9780203019900

Snyder, L. G., \& Snyder, M. J. (2008). Teaching critical thinking and problem solving skills. The Journal of Research in Business Education, 50(2), 90.

Sriwongchai, A. (2015). Developing the mathematics learning management model for improving creative thinking in Thailand. International Education Studies, 8(11), 77. https://doi.org/10.5539/ies.v8n11p77

Sternberg, R. J. (2006). The nature of creativity. Creativity Research Journal, 18(1), 87-98. https://doi.org/10.1207/s15326934crj1801_10

The English Language Curriculum Section (ELCS). (2010). English language curriculum framework. Muscat, Sultanate of Oman: Ministry of Education.

Torrance, E. P. (1963). Education and the creative potential. Minneapolis, MN: The University of Minnesota Press.

Torrance, E. P. (1995). Why fly? A philosophy of creativity. Series: Creativity Research. In M. A. Runco (Series Ed.). Norwood, NJ: Ablex Publishing Corporation.

Torrance, E. P., \& Safter, H. T. (1990). The incubation model of teaching: Getting beyond the aha! Buffalo. New York: Bearly Limited.

Torrance, E. P., Goff, K., \& Satterfield, N. B. (1998). Multicultural mentoring of the gifted and talented. Waco, TX: Prufrock Press. 
Treffinger, D., Young, G., Shelby, E., \& Shepardson, C. (2002). Assessing creativity: A guide for educators. Storrs, CT: The National Research Center on the Gifted and Talented.

Vidal, R. V. V. (2005). Creativity for operational researchers. Investigacao Operacional, 25(1), 1-24. Retrieved from http://www.scielo.mec.pt/pdf/iop/v25n1/v25n1a01.pdf

Vogel, T. (2014). Breakthrough thinking: A guide to creative thinking and idea generation. Georgetown, Ontario: HOW Books.

Appendix A

Examples of Some Creativity Teaching Strategies from Grade 12 Prescribed Teaching Strategies.

\begin{tabular}{|c|c|c|}
\hline Stage & $\begin{array}{l}\text { TIM } \\
\text { strategies }\end{array}$ & Examples \\
\hline \multirow{3}{*}{ 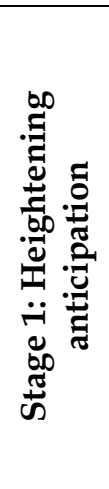 } & $\begin{array}{l}\text { Create desire } \\
\text { to know }\end{array}$ & $\begin{array}{l}\text { Ask students questions like: } \\
\text { - } \quad \text { Do you think that news and the media are interesting? } \\
\text { Give your reasons. } \\
\text { - } \quad \text { Why is it important to follow the news?(MOE, 2017a, p.2) }\end{array}$ \\
\hline & $\begin{array}{l}\text { Heightening } \\
\text { anticipation }\end{array}$ & $\begin{array}{l}\text { Ask students questions like: } \\
\text { - What kind of career(s) are you interested in? } \\
\text { - What attracts you to this kind of career (job)? (MOE, } \\
\text { 2017a, p.26) }\end{array}$ \\
\hline & $\begin{array}{l}\text { Give purpose } \\
\text { and motive. }\end{array}$ & $\begin{array}{l}\text { In groups, students read the letter and decide what advice they } \\
\text { would give to the writer (MOE, 2017a, p. 27) }\end{array}$ \\
\hline \multirow{3}{*}{ 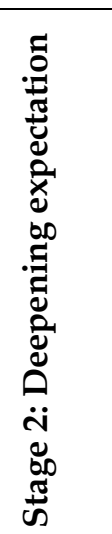 } & $\begin{array}{l}\text { Digging } \\
\text { Deeper }\end{array}$ & $\begin{array}{l}\text { Ask students to read the information about reading, then discuss } \\
\text { the three questions in groups, eliciting feedback so that students } \\
\text { can share their ideas with the whole class. Encourage them to } \\
\text { share their solutions to improve their reading speed (MOE, } \\
\text { 2016a, p. 28) }\end{array}$ \\
\hline & $\begin{array}{l}\text { Listening for } \\
\text { smells }\end{array}$ & $\begin{array}{l}\text { Organize students into pairs. One students is 'Student A'. The } \\
\text { other students is 'Student B'. Students read the scenarios and } \\
\text { then role play the situations (MOE, 2017a, p. 76). }\end{array}$ \\
\hline & $\begin{array}{l}\text { Cutting holes } \\
\text { to see } \\
\text { through }\end{array}$ & $\begin{array}{l}\text { Students complete the gapfill activity. Tell them that before } \\
\text { trying to fill in the gaps, they should read the whole text first in } \\
\text { order to get the gist of it ((MOE, 2017a, p. 28). }\end{array}$ \\
\hline \multirow{3}{*}{ 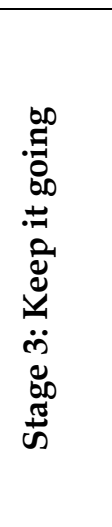 } & Having a ball & $\begin{array}{l}\text { This fun activity reviews some of the key vocabulary in Units 1-3 } \\
\text { of the themes... To make the activity more challenging, ask more } \\
\text { advanced students to see if they can complete the crossword } \\
\text { without looking back through the units (MOE, 2017a, p. 13) }\end{array}$ \\
\hline & $\begin{array}{l}\text { Singing in } \\
\text { one's own } \\
\text { key }\end{array}$ & $\begin{array}{l}\text { Students work with a partner and practice making up sentences } \\
\text { about themselves using past perfect (MOE, 2016a, p. 32) }\end{array}$ \\
\hline & $\begin{array}{l}\text { Building and } \\
\text { castles }\end{array}$ & $\begin{array}{l}\text { Students choose one headline in Course book, page } 7 \text {, activity } 4 \\
\text { and write a short story to go with that headline. To help them, } \\
\text { they should use the vocabulary they have predicted for that story } \\
\text { (MOE, 2017a, p. 12). }\end{array}$ \\
\hline
\end{tabular}

